\title{
THE WOMAN BODY IN REVIEW: THE IMPERATIVE OF BEAUTY ${ }^{1}$
}

\author{
Rúbia Guimarães Ribeiro², Maria Henriqueta Luce Kruse
}

${ }^{1}$ Article elaborated based on the dissertation - Todo lo que interesa a la mujer: discursos sobre saúde na revista Para Ti, from the Nursing Graduate Program of the Federal University of Rio Grande do Sul (UFRGS), 2012.

${ }^{2}$ Master in Nursing. R.N. Rio Grande do Sul, Brazil. E-mail: rubiagribeiro@yahoo.com.br

${ }^{3}$ Ph.D. in Education. Associate Professor of the Nursing School of UFRGS. Rio Grande do Sul, Brazil. E-mail: kruse@uol.com.br

\begin{abstract}
The media challenges us, creating ways of life and showing us how to behave in various situations. Therefore, we propose to understand the investments on beauty conveyed on Para Ti magazine, in 1940, reflecting on the possible conditions of such messages and the way they circulated producing a subjective mindset and teaching their readers how to be beautiful. We understand that the media provides material with which people forge their identity. This is a qualitative study based on post-structuralist cultural studies. The research corpus consists of issues of the Argentinean magazine Para Ti, from 1940. A cultural analysis was carried out based on concepts suggested by philosopher Michel Foucault, such as power and discipline. These analyses were organized under the marker named "the imperative of beauty". Considering the content presented by the magazine, it is possible to understand the relationship we have with today's image of a beautiful body, associating it with thinness, a balanced diet, exercise, normality, and health.
\end{abstract}

DESCRIPTORS: History. Human body. Beauty.

\section{O CORPO DA MULHER EM REVISTA: O IMPERATIVO DA BELEZA}

RESUMO: A mídia nos interpela, produz modelos de vida, nos mostra como devemos agir nas mais variadas situações. Sendo assim, propomos conhecer os investimentos na beleza veiculados na revista Para Ti, no ano de 1940, refletindo sobre suas condições de possibilidade e os modos como circulavam produzindo subjetividades e ensinando suas leitoras a serem belas. O estudo é de natureza qualitativa, tendo como base os Estudos culturais, em sua versão pós-estruturalista. Constituíram o corpus da pesquisa 23 exemplares da revista argentina Para Ti do ano de 1940. Foi realizada uma análise cultural apoiada em teorizações sugeridas pelo filósofo Michel Foucault, como poder e disciplina. As análises foram organizadas no marcador intitulado "o imperativo da beleza". A partir do que a revista apresenta, podemos entender as relações que mantemos com a imagem de um corpo belo hoje, conectando-o à magreza, a uma alimentação balanceada, à prática de exercícios, à normalidade, à saúde.

DESCRITORES: História. Corpo humano. Beleza.

\section{EL CUERPO DE LA MUJER EN REVISTA: EL IMPERATIVO DE LA BELLEZA}

\begin{abstract}
RESUMEN: Los medios de comunicación nos desafían, hacen que los modelos de vida, nos muestre cómo debemos actuar en diversas situaciones. Por lo tanto, proponemos analizar las inversiones en la belleza transmitidas en la revista Para Ti, en el año de 1940, reflejando sobre las condiciones de posibilidad de esos discursos y los modos cómo circulaban produciendo subjetividades y enseñando a sus lectoras a ser lindas. Entendemos que los medios ofrecen material con el que las personas forjan su identidad. El estudio es de naturaleza cualitativa, teniendo como base los estudios culturales, en su versión post-estructuralista. Constituyeron el corpus de la investigación ejemplares de la revista argentina Para Ti del año de 1940. Se realizó un análisis cultural apoyado en teorizaciones sugeridas por el filósofo Michel Foucault, como poder y disciplina. Los análisis fueron organizados en el marcador intitulado "el imperativo de la belleza". A partir de lo que la revista presenta, podemos entender las relaciones que mantenemos con la imagen de un cuerpo bello hoy, conectándose a la delgadez, a una alimentación balanceada, a la práctica de ejercicios, a la normalidad, a la salud.
\end{abstract}

DESCRIPTORES: Historia. Cuerpo humano. Belleza. 


\section{INTRODUCTION}

Media is part of our routine and it influences our actions but overall, teaches us how to act. The content conveyed by the media affects us in a direct manner, as it is part of our culture and it is constantly present in our daily life. Media challenges us, creating ways of life, showing us how to behave in various situations. It has powerful socializing effects by means of examples and subject positions, appreciating some behaviors and depreciating others. ${ }^{1}$ These teachings are part of a range of pedagogic strategies which move in a social context and question us, promoting education and ruling individuals. ${ }^{2}$ We believe that it is in the media that things move and appear the most. Thus, we are also the result of what the media seize us with. When we think of media as a place where power is exercised, we also remember that it is also considered as a body that performs the so-called cultural pedagogy, as we know that teaching is not something limited to schools. Therefore, we can assume that it educates just as another educational institution. ${ }^{4}$ Its speeches work as power strategies that form individuals and teach life styles. ${ }^{3}$ According to the cultural and social contexts in which it is found, the media objectifies people, as it chooses the messages to be spread. We believe that the media has always had the power to educate people and that we are the target of the information it spreads.

As part of the media, magazines can be conceived from a pedagogic point of view, as their messages reach a specific public and different strategies are put in place in order to address people. What we see on television, what we read in magazines and what we hear on the radio are cultural patterns that have an influence in what we think of ourselves, in our identity. ${ }^{2}$ There have been different strategies to produce truth within our society, but we believe that magazines contributed heavily to spread what is considered to be a proper behavior when it comes to body care, where the continuous search for beauty is appreciated. The dissemination of corporal practices by the written press must be highlighted, as the messages in magazines have been shaping women's body over time. Magazines can be considered as an element of a sort of pedagogy that aims to define a certain type of female body. ${ }^{4}$

We believe that the woman's image is associated with established beauty standards. The relationship between femininity and beauty goes across centuries and cultures. Nevertheless, the ways to question the appearance, to shape and determine the embellishment are constantly changed. ${ }^{5}$ There are different levels of embellishing practices, found in different sources: good shape manuals, advertisements and advice found in female magazines. Even these practices have a background and they comply with moral rules of a given society. What used to be considered as desirable and beautiful in the past can be considered as artificial in more recent times. These values change over time, thus changing the relationship between femininity and culture, between the body and embellishing practices. ${ }^{6}$

In the search for the conditions that gave way to the current form of seeing and describing a beautiful body, we went back to a magazine that was issued in 1940, in an attempt to have an overview of the body history. Therefore, we aim to analyze the messages addressed regarding the woman's body in Para Ti magazine, discussing the different possibilities of messages, considered as the mechanisms that build knowledge, and the ways they were disseminated, producing a subjective mindset and teaching their readers how to be beautiful.

Leafing through the 1940 issues of this magazine, we wonder about the investments made in the beauty of the woman's body in the beginning of the 20th century. We believe that when we think about this matter we can question the different body practices of nowadays. We are not looking for linearity or continuity of messages that were disseminated in 1940 and those of today, neither a maturation of ideas, as we do not consider contemporaneity as the latest step of progress. Having Foucault's ideas in mind, it becomes evident that it is important not to seek transformations undergone by a certain individual within a certain society, but to question what is natural and turn it into something historical. ${ }^{7}$

In this context, we define the aim of this article: to understand the investments made in beauty with the help of Para Ti magazine. The analysis of the corpus is important so we can understand the different possibilities and the history of body practices until today. As practices and habits of health care are constantly associated with beauty, we believe that this study contributes to nursing practice and women's health preservation. 


\section{METHOD}

This is qualitative study of 23 issues of the Argentinean magazine Para Ti, issued between January 2nd and June 25th of 1940. This is a weekly magazine that is still currently published. As Para Ti was the first female magazine of Latin America, it was widely distributed in Brazil. Widespread among women, the print run varied between 250,000 to 280,000 copies. We chose this magazine because it is targeted to female readers, it talks about health and beauty topics and it is supported by influent people and companies.

Based on post-structuralist cultural studies, we assume that culture comprehends a range of practices and representations such as texts, pictures, talks and codes of behavior, which all have an influence on social life. ${ }^{8}$ As well as the post-structuralist analyses, cultural studies do not adopt the approach that points to the existence of a privileged place that inspires knowledge. For that reason, it is necessary to look for all the possible messages, that is, the mechanisms that allow the construction of knowledge. ${ }^{9}$ In order to explore the messages contained in the magazine, we used a cultural analysis. This type of analysis exposes mechanisms of subordination, control and exclusion, which affect the social reality, and show the different mindsets from different times, which all have a historical and cultural value. ${ }^{9}$ Besides, we worked with some theories suggested by philosopher Michel Foucault, such as power and discipline. To understand the beauty investments found in the magazine, we look at the stimuli that are being applied so women become better looking, and we analyze these magazines so we can understand how we came to think of beauty in the way we do today.

In our analyses, we chose to use the word "marker" to indicate distinctive features that give meaning to certain analyses. We did not intend to categorize the findings hierarchically, for this reason we did not use the term "categories". The woman's image, associated with beauty standards spread by the magazine, led us to think of an "imperative of beauty", and we realize that the beauty of the woman's body was also worshiped in 1940.

One of the theories used was Foucault's understanding of power. When we realize that the body standard presented by the media is part of the different processes of human objectification that take place in our culture, it is impossible not to think of power relationships.
Moreover, we also bring to light what Foucault has seen as discipline a technique used to control and train individuals, with detailed topics on body care aimed at female readers. When we speak of imperative of beauty, we refer to some concepts that Foucault treated as "technologies of power" in the 17th and 18th centuries, when the body was given a particular attention and was seen separately, as something unique. These features allow us to have control over the body and establish a docility-utility relationship with it. Discipline is a way to exercise power, whose objective is to normalize, to detail and to organize the body; it analyzes and decomposes individuals in sufficient elements so they can be perceived and modified. ${ }^{10-12}$

This study was developed with information from public documents that did not need the approval of a Research Ethics Committee, as it does not refer to the author but rather to the place they occupy.

\section{RESULTS AND DISCUSSION}

In our discussion, we look at the messages conveyed in the magazine as a result of human practices. In this sense, we believe that many things that appear to be natural today - such as a beautiful body - are the result of a series of possible events. To Foucault, history shows that what is real today has not always been so and how "things that seem obvious to us come from the crossroads of disputes and accidents, over the course of a precarious and fragile history". ${ }^{13: 18}$

\section{Imperative of beauty}

Regarding the self-care women should have with themselves, we notice that female beauty was a frequent topic in Para Ti magazine. Such observation made us believe in the existence of an "imperative of beauty" in 1940 as well. The skin, hair, legs, arms, teeth, nails, hands, that is, different parts of the body are constantly mentioned with lots of pieces of advice to keep them admirable and beautiful. Through the media, the imperatives of beauty, of youth and longevity reach all women. Examples are given so we can find a way to be nice, fit, healthy and permanent. ${ }^{14}$ Throughout the 20th century, what was considered nice and healthy underwent a few changes. Getting a healthy and beautiful body became an individual goal and part of a woman's responsibility. ${ }^{4}$ As these teach- 
ings are conveyed in health messages, strategies to become more beautiful are strengthened and have more credibility. In an energizer advertisement, the first sentence illustrates this association: "Health is a powerful element for sympathy. No kind of beauty is more suggestive than the charm radiated by a woman full of energy, health and spirit"15:8

In the first half of the 20th century, advertisements talked about products, commonly called medicines, which fought against the "defects" of women's physical appearance. Magazines disseminated advertisements of medicines for beauty, which characterized the multi functionality of these products that healed everything, from wrinkles to wounds, fatigue to scars. Ointments that promised to taper the waist, to whiten the skin or to darken white hair were often defined as medicines. ${ }^{16}$ In an advertisement for a face cream, the heading is: "a perfect beauty with Vindobona Cream" ${ }^{\prime 17: 30}$. Then, we notice that the text focuses on the skin health. It associates the impurities found in the face with the skin malfunctioning, which the cream will fix: "the nutritive, energizing and stimulating properties of its ingredients help to get rid of impurities that are frequently the cause of the skin malfunctioning. ${ }^{17: 30}$

We notice that the magazine frequently calls upon a physician to support the teachings. We give this professional the role of what Foucault called an "expert", as he or she is a person who can talk about specific subjects that he or she masters, which is not the case for everyone. ${ }^{18}$ In a society in which a physician participates in the moral and social organization of families, considering the lack of beauty as a disease fosters the need for health care and medicine treatments. This behavior suggests the importance of medical assistance and medicines in our daily life, a trend that is still present today. As well as in the pursuit of health, medicines also help in the pursuit of beauty, which shows the strong link between beauty and health. In an advertising piece of a medicine made to improve the intestinal function, there is a clear evidence of this link: "take care of your health. The medical advice will allow you to have a healthy and efficient life. Let's not forget that to keep a healthy intestine and free it from toxins, a purifying treatment under medical supervision is recommended. For a healthy skin and a clean face, free from acne, freckles or stains." 19:16
Science is also used to support the messages as far as beauty is concerned. In many advertisements for cosmetics, the scientific argument is used to give the product more credibility. In an advertisement for a cream, ${ }^{20}$ the text says that when a product aims to take care of something so delicate as the woman's skin, there cannot be a combination of ingredients without scientific character. The highlighted sentence of the advertisement is: "the science of beauty" And it emphasizes: "Sanacutis Cream is scientifically made." 20-36 Another cream also shows its efficiency using science as support: "Ocacia is a scientific product that regenerates and rejuvenates your complexion" 21:60 Apart from the creams, some soaps also use the scientific argument: "Palmolive is made with a scientifically studied formula." 22:17 The media teams up with the scientific argument, and this link ensures legitimacy and credibility. Science plays a key role in the production of arguments considered as true. We can certainly see it as the most powerful set of truths invented by modern society.

Among these teachings, the search for a slim body appears to be an important component of health and beauty. In this current cult of the body, aesthetic and health trends are related, as a healthy and beautiful body becomes one. Within this current, obesity goes against both beauty and health standards, thus becoming a great hardship. In this way, physical exercise and diet are converging elements of the health and beauty speech. ${ }^{24}$ In a feature story named "Slenderness requires diet" 25:66, women's great concern about weight loss is mentioned. For this reason, according to the text, a woman can undergo strict treatments trying to achieve that goal, and can actually damage her health. The article explains that, to achieve a slender silhouette, some changes in lifestyle are necessary, which go from watching the diet to the practice of physical exercises, which are considered healthy methods. The text points out that it is not possible to be slender without any worry, as becoming slim requires "a life method regimen". ${ }^{25: 66}$

In a section called "Information for women"26:90, physical exercise appears as essential in the pursuit of a slim body: "Staying slim requires the daily practice of exercises that work preferably the abdomen and burn fat." 26:90

In a feature story called "Obesity and the table", $27: 71$ the text explains the causes of obesity 
and associates it with many diseases. It also comments about the ideal treatment for the obese, including tips such as the decrease of food intake and the stimulus of renal and intestinal functions. The mistaken belief that associates health with fat is mentioned, and a strong reason for staying slim is given: "[...] for the aforementioned cases, it is recommended to begin a slimming treatment, but under strict medical supervision, because fat is not, as one could think, an evidence of health, but quite the contrary." 27:71 We can also see here the presence of a medical message in regards to people's health. Besides preventing diseases, the physician is the person who must care for obesity and slimming matters, avoiding the risks of weight related diseases.

The magazine states that a beautiful and healthy body requires persistence and discipline. We must not forget that, within any society, the body is subject to limitations, prohibitions and obligations. ${ }^{11}$ Foucault ${ }^{28}$ says that, from the end of the 18th to the 20th century, it was believed that the investments in power should be dense, rigid and constant. Nevertheless, power did not have only a repressive role, because if it was used for censorship sake and in a negative way, it would be very fragile. Its force came exactly from the positive effects it could have, both in will and knowledge. Power produces knowledge. Through a set of rules it was possible to build a physiologic and organic knowledge of the body. In the aforementioned story "Slenderness requires diet", ${ }^{25: 66}$ the text teaches certain things about the slim body and encourages the wish for that body. The conclusions give a few more reasons for readers to follow the advice: "Slenderness is essential to reduce age, at least in appearance, to keep youth and the flexibility needed for a graceful and elegant gait" ${ }^{25: 66}$

The search for a slim body is seen as a strategy in which the technology of disciplinary power prevails. As discipline tries to rule over individuals that must be watched, trained and sometimes punished, it establishes the actions training that must be applied in order to achieve the ideal body. ${ }^{29}$ When the individual is considered singularly, the actions to be taken in order to achieve a slim body nutrition and physical activity are possible. In a feature story entitled "Exercises to taper the silhouette", 30:66 different exercises that help lose weight are taught. It also explains that a slim and healthy body is obtained after following several procedures, and we found out that discipline supports that. After all, in order to have a slender silhouette, we must have discipline be careful what we eat and practice exercises regularly: "although diet plays an important role in the silhouette slenderness, only regular physical exercises can keep it in line and with an adequate weight, and that is especially true for people who need to burn fat and lose weight. Gymnastics, apart from what it represents to women's embellishment, activates the body, making it healthier, with a fresher skin, a more vivid looking, etc" 30:66

To Foucault, ${ }^{29}$ the rule is applicable to both the body and people, it allows to control the disciplinary order of the body and the random events of a biological diversity. In a standardized society, disciplinary rules and regulations intersect. When it is said that power has taken care of life, we notice that it has covered all the population, through disciplinary technologies on one hand, and through regulation technologies on the other hand, making it two-pronged. Moreover, Foucault ${ }^{10}$ discussed the prescriptive nature of the rule, as it is in regards to this established rule that it is possible to determine what is normal or abnormal. As an example of a speech considered as normal, we mention the picture of a slim body associated with health. The fat free body is considered normal and healthy. It is based on that reference that abnormal bodies are determined, those which are not under the rules, bodies considered as ill or more likely to become ill. In a topic of the "Information for women" section $^{31: 90}$, the message about obesity is associated with diseases: "overfeeding gives way to serious food poisoning, it changes the functioning of the liver and the kidneys and leads to obesity and all of its harmful consequences." ${ }^{31: 90}$

In a section called "City squares", $32: 17$ one of the topics addressed is the slim body. A text entitled "The ideal silhouette" talks about an elegant woman who walks around the city and makes all women from all ages stop to admire her. When asked about who is the object of such admiration, whether it is a Hollywood star or a national theater artist, the answer is: "neither! The one who elicits admiration from women is a young lady whose 'stylish' silhouette is made of just one line, so slim that the outfit she's wearing in printed fabric seems to float by itself $[\ldots]^{\prime \prime}$. $^{32: 17}$ The text also speaks about the fact that some newspapers or magazines state that the fashion- 
able female silhouette is the one "with curves", but it warns: "Lie! A big lie to console those who have them! The thinness, the slenderness is still the ideal of beauty". ${ }^{32: 17}$ It also talks about the complaints from physicians and hygienists who are concerned with malnutrition and consider it as a danger for health. This way, the magazine shows the counter message about the ideal silhouette, making sure to have warned about the possible risks of the pursuit of weight loss. We mention this because, despite the careful medical speech, the message conveyed is that the slim body is the target, and it is above health. Hence, a slim body is associated with normality. Who does not want to be considered normal? Obese are put aside, they are abnormal when it comes to the idealization of the body. They are the exception: "in this search for significance and for new representations in line with the 20th century, obesity becomes a sign of illness and ugliness, and slimness a sign of health and beauty." ${ }^{4: 33}$

\section{CONCLUSIONS}

Foucault ${ }^{11}$ thought of the soul as something lying within us, on the surface and around us, through the work of a power exercised for those who are punished, watched, controlled. A soul that works like a gear in which power relationships give rise to a possible knowledge that strengthen the effects of such power. "The person who we are told about and asked to free is the effect itself of a deeper subjugation. A 'soul' that lies within and gives existence, and which is an element of power control over the body. The soul, an effect and an instrument of political anatomy; the soul, the body's prison"11:32 We brought this quote to light because we believe we are led to think in a particular way, through different strategies.

Looking back, it is possible to understand the relationship we have with today's image of a beautiful body, associating it with thinness, a balanced diet, exercise, normality, and health. Leafing through the pages of this magazine, we notice that these relationships already existed in 1940. The practice of physical exercises and a balanced diet represent the teachings that aim to disseminate the idea that a beautiful and healthy body is a slim one. In the 20th century, there was an inversion in regards to fat, which was associated with beauty and health in the previous centuries. Slenderness has become the new ideal of beauty and fat has been associated with a lack of control over the body. ${ }^{4}$ Thinking of the changes in beauty standards, we recall that the body has a multifaceted reality, being a heterogeneous and historical object. It is precisely because of this historical character that the body is (re)built over time, belonging more to history than to nature. It can be thought of as a temporary result of relationships within society, as a process. ${ }^{6}$

We observe that the beauty issue runs through the idealized slim body, which we have been dealing with for quite a long time. Since at least the 1920s, our society has begun to harbor a gradual aversion to fat people..$^{33}$ By means of our bodies, we transmit very deep social meanings; one of them is that the girth represents, to the eyes of those who see it, part of the food that we take, which metaphorically represents our part in wealth distribution. As if our loyalty was represented by distribution rules and our adherence to the social cohesion. Thus, fat people are seen as people who cannot control themselves, as offenders who break the rules of nutrition, of desire and self-control. Nevertheless, we bear in mind that we must be aware of the body measures criteria, as they vary greatly according to different cultures and time. A hundred years ago, in western countries, fat people were more loved and admired, fat was associated with health and wealth. To be considered obese, it was necessary to be fatter than in today's standards. Nevertheless, today, in the same countries, thin people are more loved and admired. ${ }^{34}$

When addressing the history of the modern individual, Foucault also addressed the political history of the body. The author states that the body is also in a political context, as it is the object of power relationships that rule its actions. The knowledge of the body does not necessarily correspond to the knowledge of its functioning, and the control over its forces goes beyond the capacity to control these forces. Foucault dealt with this knowledge and forces as a political technology of the body. This technology cannot be seen in a particular institution nor in the State; it is found in a completely different level, as a microphysics of power. In it, power is exercised not as property but as a strategy; with techniques and tactics that give its domination effects. Its relations are found within society. ${ }^{11}$ We took Para Ti magazine as an element of this strategy, a part of the dissemination process of different speeches, among which the one that includes 
what is considered to be beautiful, making the practices to achieve a beauty standard to be sought mostly by women.

Looking at these magazines published in 1940, we try to understand how we started to think of a nice body the way we do. It is not our role to fight for a particular cause, defending or criticizing the actions that we take in the search for beauty; if we did so, we would be giving prior responses and forgetting that we write to learn, to give meaning. We try to be aware in regards to what is considered natural, to powerful and unquestionable truths that take hold of us. To write in a post-structuralist approach is to throw more and more questions about inherited ideas. To question what is taken for granted, to question the unquestionable. It may seem simple, but it is more challenging than to follow certain prescriptions that are considered true and finished.

\section{REFERENCES}

1. Kellner D. Televisão, propaganda e construção da identidade pós-moderna. In: Kellner D. A cultura da mídia. Bauru (SP): EDUSC; 2001. p. 295-334.

2. Andrade SS. Mídia, corpo e educação: a ditadura do corpo perfeito. In: Meyer DE, Soares RFR. Corpo, gênero e sexualidade. Porto Alegre (RS): Mediação; 2004. p.106-20.

3. Niemeyer F, Kruse MHL. Constituindo sujeitos anoréxicos: discursos da revista Capricho. Texto Contexto Enferm [online]. 2008 [acesso 2013 Mai 27]; 17(3). Disponível em: http://www.scielo. br / scielo.php?script $=$ sci_arttext\&pid $=$ S010407072008000300006\&lng=pt\&nrm=iso

4. Andrade SS. Uma boa forma de ser feliz: representações de corpo feminino na boa forma [dissertação na Internet]. Porto Alegre (RS): Universidade Federal do Rio Grande do Sul. Faculdade de Educação; 2002 [acesso 2011 jul 28]. Disponível em: http://www.lume.ufrgs. br/bitstream/handle/10183/1623/000353790. pdf? sequence $=1$

5. Kruse FL. A propaganda moldando o corpo da mulher: uma análise da revista Para Ti na década de 40 [trabalho de conclusão de curso]. Porto Alegre (RS): Pontifícia Universidade Católica do Rio Grande do Sul; 2009.

6. Sant' Anna DB. Apresentação. In: Sant' Anna DB. Políticas do corpo. São Paulo (SP): Estação Liberdade; 1995. p. 11-8.

7. Kruse MHL. Os poderes dos corpos frios: das coisas que ensinam às enfermeiras. Brasília (DF): ABEn; 2004.
8. Frow J, Morris M. Estudos culturais. In: Denzin N. O planejamento da pesquisa qualitativa: teorias e abordagens. Porto Alegre (RS): Artmed; 2006. p.315-44.

9. Costa MV. Estudos culturais - para além das fronteiras disciplinares. In: Costa MV. Estudos culturais em educação: mídia, arquitetura, brinquedo, biologia, literatura, cinema. Porto Alegre (RS): Ed. da UFRGS; 2000. p.13-36.

10. Foucault M. Segurança, território, população. São Paulo (SP): Martins Fontes; 2008

11. Foucault M. Vigiar e punir. Petrópolis (RJ): Vozes; 2009.

12. Foucault M. História da sexualidade I: a vontade de saber. São Paulo (SP): Graal; 2010.

13. Oksala J. Como ler Foucault. Rio de Janeiro (RJ): Zahar; 2011.

14. Fischer RMB. O dispositivo pedagógico da mídia: modos de educar na (e pela) TV. Educ Pesq [online]. 2002 [acesso 2011 Mai 04]; 28(1). Disponível em: http:/ / www.lume.ufrgs.br/bitstream/ handle/10183/19240/000095967.pdf?sequence=1

15. Bioforina líquida de Ruxell. Rev Para Ti. 1940 Mai; 941:88.

16. Sant'Anna DB. Cuidados de si e embelezamento feminino: fragmentos para uma história do corpo no Brasil. In: Sant' Anna DB. Políticas do corpo. São Paulo (SP): Estação Liberdade; 1995. p.121-39.

17. Crema de oriente Vindobona. Rev Para Ti. 1940 Abr; 934:30.

18. Foucault M. A ordem do discurso. São Paulo (SP): Loyola; 2007.

19. Cuide de su salud. Rev Para Ti. 1940 Abr; 935:16.

20. Crema sanacutis. Rev Para Ti. 1940 Abr; 934:36.

21. Ocacia. Rev Para Ti. 1940 Abr; 937:60.

22. Frescura y belleza. Rev Para Ti. 1940 Abr; 935:17.

23. Costa MV. Uma agenda para jovens pesquisadores. In: Costa MV. Caminhos investigativos II: outros modos de pensar e fazer pesquisa em educação. Rio de Janeiro (RJ): DP\&A; 2002. p.143-156.

24. Mira MC. O leitor e a banca da revista: o caso da Editora Abril. [Tese]. Campinas (SP): Universidade Estadual de Campinas. Instituto de Filosofia e Ciências Humanas; 1997

25. La esbeltez requiere um regimen. Rev Para Ti. 1940 Abr; 934:66.

26. Informaciones femeninas. Rev Para Ti. 1940 Abr; 938:90.

27. La obesidad y la mesa. Rev Para Ti. 1940 Mar; 933:71.

28. Foucault M. Poder-corpo. In: Foucault M. Microfísica do poder. Rio de Janeiro (RJ): Graal; 2005. p.81-5.

29. Foucault M. Em defesa da sociedade. São Paulo (SP): Martins Fontes; 2000. 
30. Ejercicios para afinar la silueta. Rev Para Ti. 1940 Jun; 944:66.

31. Informaciones femeninas. Rev Para Ti. 1940 Mai; 942:90.

32. Cuadritos de la ciudad. Rev Para Ti.1940 Fev; 926:17.

33. Sant'Anna DB. Notas sobre peso e velocidade dos corpos. In: Sant'Anna DB. Corpos de passagem: ensaios sobre a subjetividade contemporânea. Campinas (SP): Estação Liberdade; 2001. p.13-26.

34. Fischler C. Obeso benigno, obeso maligno. In: Sant'Anna DB. Políticas do corpo. São Paulo (SP): Estação Liberdade; 1995, p. 69-80. 